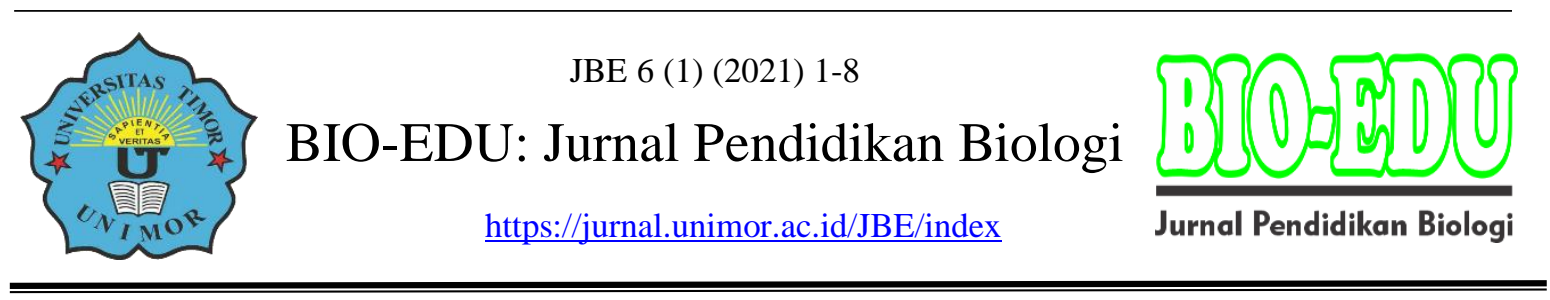

\title{
Identifikasi Media Pembelajaran Pada Materi Biologi Dalam Meningkatkan Pemahaman Konsep Peserta Didik di Masa Pandemi Covid-19
}

\section{Salsabila Tasyari' ${ }^{1}$, Fadila Nur'anfa Putri ${ }^{1}$, Alifa Alya Aurora ${ }^{1}$, Salwa Nabilah ${ }^{1}$, Yodellia Syahrani ${ }^{1}$ Ade Suryanda ${ }^{1}$}

\author{
${ }^{1}$ Program Studi Pendidikan Biologi, Fakultas Matematika dan Ilmu Pengetahuan \\ Alam, Universitas Negeri Jakarta \\ SalsabilaTasyari_1304619012@mhs.unj.ac.id
}

DOI: https://doi.org/10.32938/jbe.v6i1.905

\begin{abstract}
Abstrak
Covid-19 merupakan jenis virus baru yang baru ditemukan dan menyebabkan pandemi di seluruh dunia termasuk Indonesia dan menghambat semua aktivitas termasuk bidang pendidikan. Keadaan ini memaksa semua jenjang pendidikan berubah sistem dari yang sebelumnya tatap muka menjadi daring. Oleh karena itu diperlukan suatu inovasi dalam kegiatan pembelajaran berbasis teknologi yang salah satunya dengan memaksimalkan media pembelajaran. Penggunaan media pembelajaran di masa pandemi berperan penting dalam membantu peserta didik memahami materi Biologi yang abstrak. Metode penelitian ini yaitu menggunakan metode penelitian kualitatif dengan cara meneliti kepustakaan atau library search. Tujuan penelitian ini untuk mengidentifikasi media pembelajaran pada materi Biologi dalam meningkatkan pemahaman konsep peserta didik di masa pandemi Covid-19. Berdasarkan media pembelajaran berbasis manusia, media cetak, media visual, media audio visual, dan media komputer (web), diketahui bahwa media pembelajaran berbasis animasi dianggap paling berpeluang karena dapat meningkatkan hasil belajar peserta didik.
\end{abstract}

Kata Kunci: Animasi, Media Pembelajaran, Biologi

\section{Abstract}

Covid-19 is a new type of virus that has just been discovered and has caused a pandemic throughout the world including Indonesia and hampers all activities including the education sector. This situation forces all levels of education to change the system from previously face-to-face to online. Therefore we need an innovation in technology-based learning activities, one of which is by maximizing learning media. The use of learning media during a pandemic plays an important role in helping students understand abstract Biology material. This research method is a qualitative research method by means of library research or library search. The purpose of this research is to improve students' understanding while studying in the pandemic era by using learning media. Based on human-based learning media, print media, visual media, audio-visual media, and computer media (web), it is known that animation-based learning media is considered the most likely because it can improve student learning outcomes.

Keywords: Animation, Learning Media, Biology 


\section{PENDAHULUAN}

Covid-19 merupakan salah satu jenis virus baru yang baru ditemukan pada tahun 2019. Infeksi Corona Virus Disease 2019 pertama kali terdeteksi pada bulan Desember 2019 di Cina dan telah menyebar dengan cepat ke seluruh dunia (Retnaningsih et al., 2020) termasuk Indonesia dan menghambat semua aktivitas termasuk bidang pendidikan. Situasi ini menantang sistem pendidikan di seluruh dunia dan memaksa pendidik untuk beralih ke mode pengajaran secara daring dalam sekejap. Menurut Surat Edaran Nomor 4 Tahun 2020 tentang Pelaksanaan Kebijakan Pendidikan Dalam Masa Darurat Penyebaran Covid, proses pembelajaran dilakukan di rumah melalui pembelajaran daring yang menggunakan jaringan internet dan alat perantara seperti gadget, laptop. Dalam hal ini maka perkembangan teknologi secara inovatif dalam media pembelajaran sangat dibutuhkan.

Saat ini dunia telah memasuki era dengan ciri penggunaan teknologi semakin diutamakan yaitu era revolusi industri 4.0. Berbagai aspek kehidupan seperti pada beberapa bidang yaitu ekonomi, politik, kebudayaan, seni, dan bahkan hingga ke dunia pendidikan telah dipengaruhi oleh era ini (Abdurahman, 2017). Berkembangnya teknologi secara pesat membuat dunia pendidikan dituntut harus mengikuti perkembangan zaman yang ada. Dengan memanfaatkan secara maksimal teknologi informasi dan komunikasi membuat proses pembelajaran menjadi lancar dan merubah pola pikir pembelajaran yang dahulu berpusat pada guru sekarang menjadi berpusat pada peserta didik.

Penerapan teknologi informasi dan komunikasi telah tersebar di seluruh dunia termasuk Indonesia. Hal inilah yang menjadikan peluang untuk meningkatkan kualitas pendidikan dan sumber daya yang bagus dalam proses pengajaran dan pembelajaran. Selain itu terdapat dua faktor yang memengaruhi hasil belajar yaitu ada faktor internal seperti minat belajar yang berhubungan langsung terhadap hasil belajar dan faktor eksternal. Pemakaian teknologi dengan bijak dan benar dapat meningkatkan kualitas pendidikan dan mengubah proses pembelajaran yang terbilang monoton, berpusat pada guru, dan buku dalam pembelajaran di kelas menjadi pembelajaran yang menarik (Haris Budiman, 2014; Melati, 2011). Oleh karena itu diperlukan suatu inovasi dalam kegiatan pembelajaran berbasis teknologi seperti memanfaatkan media animasi agar gaya dan model belajar peserta didik menjadi lebih disenangi peserta didik dan peserta didik terhindar dari rasa jenuh dan bosan saat mengikuti pembelajaran. Pembelajaran yang dengan unsur utama yaitu teknologi sangat membantu peserta didik dalam memahami suatu pembelajaran dengan baik (Muali et al., 2018).

Menurut (Leshin et al., 1992) dalam (Kholipah et al., 2020) dikatakan bahwa media berbasis guru manusia, media berbasis cetak, media berbasis visual,media berbasis audiovisual,dan media berbasis computer merupakan klasifikasi media. Adapun tujuan dari studi literatur ini yaitu untuk mengidentifikasi media pembelajaran pada materi Biologi dalam meningkatkan pemahaman konsep peserta didik di masa pandemi.

\section{METODE}

Metode pengambilan data dilakukan yaitu metode penelitian kualitatif dengan cara penelitian kepustakaan atau library search. Informasi yang dibutuhkan dalam penyelesaian penelitian tersebut diperoleh dari berbagai literatur baik buku, jurnal 10 tahun terakhir, maupun hasil penelitian sebelumnya yang relevan. Menurut (Zed, 2014) 
terdapat prosedur penelitian kepustakaan yaitu :

1. Memilih topik pembahasan dengan cara mengamati permasalahan dalam fenomena pendidikan sekitar

2. Mencari informasi melalui peserta didik, tenaga pendidik, dan media lainnya

3. Menentukan sebuah fokus penelitian berdasar pada informasi yang telah didapat sebagai prioritas pembahasan

4. Mengumpulkan data berupa informasi yang dihimpun dari buku, jurnal, hasil laporan penelitian sebelumnya, dan literatur lain yang mendukung tema penelitian

5. Membaca data sumber penelitian yang mengharuskan pembaca untuk menggali bahan bacaan lebih dalam yang memungkinkan penemuan ide baru yang berkaitan dengan penelitian

6. Membuat catatan penelitian yang berfungsi sebagai pengingat dan penghimpun informasi penting dari bahan bacaan

7. Mengolah catatan penelitian guna mendapatkan kesimpulan dalam bentuk artikel penelitian

8. Menyusun artikel penelitian sesuai dengan sistematika penulisan yang berlaku

\section{HASIL DAN PEMBAHASAN}

Pembelajaran Biologi pada umumnya di beberapa sekolah cenderung masih menggunakan bentuk media fisik dan tidak tersambung dengan kecerdasan teknologi seperti papan tulis, lembar kerja siswa, torso, dan buku cetak yang tergolong masih konvensional. Hal ini menunjukkan bahwa pada bidang Biologi pada aspek pengembangan media pembelajaran oleh guru ataupun ahli pendidikan masih belum variatif. Melihat keadaan dunia yang sedang diterpa pandemi tentunya membawa keadaan baru pada peserta didik untuk belajar. Adapun penggunaan media cetak yang digunakan saat pembelajaran Biologi di saat pembelajaran secara daring memiliki kekurangan yaitu lambat dalam penyampaiannya sebab perlu menunggu proses cetak dan pendistribusian barang yang terlambat (Suyasa \& Sedana, 2020). Selain itu pada penggunaan media cetak hanya dapat menampilkan tulisan atau gambar. Keterbatasan dari media cetak tersebut akan membuat peserta didik merasa sulit dan terhambat untuk memahami materi Biologi. Selanjutnya ketika pembelajaran Biologi masih menggunakan media berbasis manusia atau guru di era pandemi maka akan sulit dilakukan karena kemungkinan untuk interaksi secara lagsung dengan semua peserta didik tidak diperbolehkan karena telah diterapkannya social ditancing. Social distancing merupakan salah satu upaya dari pemerintah dimana seseorang diwajibkan untuk menjaga jarak, misalnya keharusan untuki menghindari kerumunan dan berkontak fisik dengan orang lain (Handarini \& Wulandari, 2020).

Di era digital seperti sekarang ini, akses internet bukan lagi menjadi hal baru terutama di dunia pendidikan. Pada penelitian yang dilakukan oleh (Firmansyah \& Saidah, 2016) diketahui bahwa media pembelajaran berbasis web dapat memberi kesan suasana belajar yang tidak biasa serta sumber belajar yang beragam. Namun, hal tersebut justru terkadang membuat peserta didik kewalahan dengan fitur-fitur yang terlalu bervariasi, ditambah lagi dengan banyaknya bahasa komputer yang sulit dipahami peserta didik. Kesulitan dan masalah yang terkait dengan teknologi ini berkisar dari kesalahan pengunduhan, masalah penginstalan, masalah login, konten online semuanya bersifat teoritis dan tidak membiarkan peserta didik berlatih, dan 
keinginan peserta didik untuk interaksi dua arah yang sulit diterapkan (Dhawan, 2020). Media pembelajaran berbasis web seperti ini memang membuat kegiatan belajar mengajar menjadi sangat fleksibel Namun, sudah menjadi rahasia umum bahwa jangkauan internet di setiap daerah di Indonesia masih belum merata dan harga akses internet yang cukup terbilang mahal bagi beberapa orang (Daheri et al., 2020; Sahroni \& Nuryuniarti, 2020; Syah, 2020).

Salah satu media yang cukup digunakan untuk menunjang pembelajaran Biologi yaitu media visual. Menurut penelitian yang dilakukan (Yusmiono, 2018) bahwa pemanfaatan media visual selama proses belajar mengajar dapat membantu peserta didik dalam pemahaman konsep. Media visual merupakan suatu media yang hanya mengandalkan indra penglihatan untuk menerima pemahaman pesan atau informasi yang dikandung secara menyeluruh. Hal tersebut akan menjadi kelemahan jika diterapkan. Selain itu, ketika mempelajari suatu siklus yang tergolong materi yang terlalu kompleks maka kurang efektif untuk kegiatan pembelajaran (Mumtahanah, 2014).

Media pembelajaran yang sedang digencarkan saat ini yaitu media audio visual yang biasanya akan menggunakan media komputer atau laptop dalam menyajikan video atau animasi yang ditampilkan dalam bentuk GIF ataupun powerpoint (Sangaji et al., 2019). Media audio visual merupakan gabungan antara audio dan visual yang diharapkan akan lebih memudahkan untuk belajar Biologi secara mandiri di masa pandemi (Dwijayani, 2019). Media animasi merupakan sebuah media pembelajaran yang mampu memberikan gambaran nyata dari wujud dan siklus kerja dari suatu obyek. Gambaran yang dimaksud dalam hal ini, mengenai cara kerja suatu sistem organ pada materi biologi. Media animasi juga dapat meningkatkan efektivitas pembelajaran karena peserta didik akan lebih mudah dalam memahami materi yang disampaikan dalam proses pembelajaran. Dalam penelitian yang dilakukan oleh (Muyaroah \& Fajartia, 2017), dikatakan bahwa materi bahkan soal-soal latihan yang dipaparkan menggunakan media pembelajaran berbasis animasi membuat siswa tidak mudah bosan saat belajar.

Penggunaan animasi sebagai media pembelajaran juga lebih efektif daripada penggunaan visual saja. Pendapat ini juga di dukung oleh penelitian sebelumnya yaitu (Oktarini et al., 2014) yang menyatakan bahwa ada pengaruh penggunaan media animasi terhadap hasil belajar peserta didik dan lebih efektif meningkatakan hasil belajar peserta didik secara signifikan dibandingkan media visual. Media pembelajaran berbasis animasi dapat meningkatkan hasil belajar speserta didik terhadap materi biologi yang sifatnya abstrak dan juga media pembelajaran animasi dinilai lebih unggul daripada pembelajaran dengan bantuan media gambar manual (Fuady \& Mutalib, 2018; Oktarini et al., 2014; Utomo et al., 2020).

Dalam pengajaran materi biologi diperlukan solusi untuk mengatasi suatu kesulitan belajar peserta didik. Oleh karena itu, dalam menunjang pemahaman peserta didik terhadap materi yang diberikan, guru memerlukan media pembelajaran yang dapat memaksimalkan peserta didik dalam memvisualisasikan suatu materi ajar dengan baik. Visualisasi merupakan salah satu solusi untuk memudahkan pemahaman peserta didik dalam proses pembelajaran sehingga materi pelajaran yang bersifat abstrak menjadi kongkrit (Fuady \& Mutalib, 2018). Materi-materi pembelajaran yang dianggap sulit karena terlalu verbalistis dan perlu visualisasi dapat diajarkan dengan media animasi. Pendapat ini diperkuat oleh (Slavin, 2011), yang mengemukakan bahwa pembelajaran dengan media animasi dapat membantu siswa dalam memahami konsep-konsep yang sulit. 
Pada pembelajaran materi Biologi terdapat banyak urutan proses, mekanisme, ataupun tahapan-tahapan yang sifatnya dinamis. Dengan media animasi, penjelasan untuk materi berupa tahapan ataupun mekanisme akan dapat mudah dipahami. Materi Biologi juga memiliki konsep-konsep yang terkadang sulit dipahami oleh peserta didik sebab kosakata yang digunakan terlalu asing sehingga peserta didik tidak dapat membayangkan atau mengimajinasikan apa yang sedang dibaca. Hal tersebut nantinya dapat menghambat pemahaman peserta didik terhadap suatu konsep. Penelitian yang dilakukan oleh (Hadi, 2017) menunjukkan bahwa video animasi dapat menjadi solusi untuk mengatasi kemampuan peserta didik yang rendah dalam memahami konsep. Informasi yang disajikan melalui animasi, dapat mempermudah peserta didik dalam memahami konsep-konsep pada materi biologi.

Tampilan yang muncul saat menggunakan media pembelajaran berbasis animasi sangat mendukung proses pemahaman materi. Hal tersebut sejalan dengan yang dikemukakan oleh (Wuryanti \& Kartowagiran, 2016) desain pada media pembelajaran berbasis animasi ini memiliki tampilan background yang jelas, berwarna, gambar yang menarik, bentuk teks bacaannya yang eyecatching, serta audio atau musik yang terdapat di dalamnya. Tampilan menarik tersebut akan membuat peserta didik bersemangat untuk belajar. Selain itu akan lebih banyak melakukan kegiatan belajar dikarenakan keingintahuan mereka sendiri, dan tidak hanya terpaku mendengarkan uraian guru, tetapi juga bisa mengamati, mempragakan, dan materi yang dipelajarinya.

Peluang penerapan media animasi pada proses pembelajaran dirasa lebih interaktif karena media tersebut akan menampilkan gambar yang dapat bergerak dan menimbulkan suara yang menjelaskan gambar tersebut. Sehingga pembelajaran dengan media animasi tidak hanya terfoku pada satu indera namun, akan melibatkan indra penglihatan dan indra pendengaran secara bersamaan. Semakin banyak indra yang berperan dalam pembelajaran maka peserta didik semakin mudah mengingat dan memahami materi. Pendapat ini didukung oleh (Arsyad, 2011) yang menyatakan bahwa pembelajaran semakin bermakna jika dapat melibatkan banyak indra.

Media berperan penting dalam proses pembelajaran. Oleh karena itu pada tahap pemilihan media guru harus mempertimbangkan kesesuaian media dengan materi dan kondisi peserta didik. Guru diharapkan dapat menerapkan media animasi, karena penerapan media animasi ini akan lebih menarik untuk digunakan dalam pembelajaran cara kerja sistem organ pada materi Biologi.

\section{KESIMPULAN DAN SARAN}

\section{Kesimpulan}

Berdasarkan hasil studi pustaka maka dapat disimpulkan bahwa peluang media animasi sebagai media pembelajaran pada materi Biologi dalam meningkatkan pemahaman konsep peserta didik di masa pandemi lebih besar daripada media pembelajaran yang lainnya. Media animasi merupakan sebuah media pembelajaran yang mampu menyediakan visual yang mampu bergerak dengan disertai audio yang menunjang penjelasan dari visual tersebut. Selain itu, pengggunaan media animasi yang menggunakan dua indera akan lebih bermakna ketika diterapkan oleh seorang peserta didik.

\section{Saran}

Media animasi merupakan media yang dilengkapi dengan visual yang bergerak 
dan ditunjang dengan penjelasan dari audio. Saran yang dapat disampaikan dari penulis yaitu untuk memperhatikan penggunaan visual yang terlihat simple dan menarik akan memudahkan peserta didik memahami materi Biologi. Selain itu, ketepatan tempo audio ketika menjelaskan visual juga perlu diperhatikan dengan baik agar .

\section{DAFTAR RUJUKAN}

Abdurahman. (2017). Implikasi UUSPN Terhadap Pendidikan Islam. Jurnal Manajemen Pendidikan Islam, 1(1), 19-35. https://doi.org/10.33650/altanzim.v1i1.25

Arsyad, A. (2011). Media Pembelajaran. Grafindo Persada.

Daheri, M., Juliana, Deriwanto, \& Amda, A. D. (2020). Efektifitas WhatsApp sebagai Media Belajar Daring. Jurnal Basicedu, 3(2), 524-532. https://doi.org/10.31004/basicedu.v4i4.445

Dhawan, S. (2020). Online Learning: A Panacea in the Time of COVID-19 Crisis. Journal of Educational Technology Systems, 49(1), 5-22. https://doi.org/10.1177/0047239520934018

Dwijayani, N. M. (2019). Development of circle learning media to improve student learning outcomes. Journal of Physics: Conference Series, 1321(2), 171-187. https://doi.org/10.1088/1742-6596/1321/2/022099

Firmansyah, R., \& Saidah, I. (2016). Perancangan web based learning sebagai media pembelajaran berbasis ICT. Informatika, 3(September), 176-182. https://doi.org/https://doi.org/10.31294/ji.v3i2.834

Fuady, R., \& Mutalib, A. A. (2018). Audio-Visual Media in Learning. Journal of K6, Education, and Management, 1(2), 1-6. https://doi.org/10.11594/jk6em.01.02.01

Hadi, S. (2017). Efektivitas Penggunaan Video Sebagai Media Pembelajaran untuk Siswa Sekolah Dasar. Transformasi Pendidikan Abad 21, 96-102.

Handarini, O. I., \& Wulandari, S. S. (2020). Pembelajaran Daring Sebagai Upaya Study From Home (SFH) Selama Pandemi Covid 19. Jurnal Pendidikan Administrasi Perkantoran (JPAP), 8(3), 503. https://doi.org/10.1093/fampra/cmy005

Haris Budiman. (2014). Peran Teknologi Informasi Dan Komunikasi Dalam Pendidikan. Al-Tadzkiyyah: Jurnal Pendidikan Islam, 8(I), 31-43. https://doi.org/https://doi.org/10.24042/atjpi.v8i1.2095

Kholipah, S., Maryatun, \& Pritandhari, M. (2020). Pengembangan Media Pembelajaran Ular Tangga Pada Mata Pelajaran Ekonomi Kelas X Sma Muhammadiyah 1 Metro Tahun Pelajaran 2017 / 2018. Edunomia: Jurnal Ilmiah Pendidikan Ekonomi, 1(1), 60-71.

Leshin, C. B., Pollock, J., \& Reigeluth, C. M. (1992). Instruction Design Stategies And Tactics Englewood Cliffs. Englewood Cliffs, New Jersey : Educational Technology Publications.

Melati, H. A. (2011). Meningkatkan aktivitas dan hasil belajar siswa sman 1 sungai ambawang melalui pembelajaran model. Jurnal Visi Ilmu Pendidikan, 6(3), 619630. https://doi.org/http://dx.doi.org/10.26418/jvip.v6i3.53

Mumtahanah, N. (2014). Penggunaan Media Visual dalam Pembelajaran PAI. All 
Hikmah Jurnal Studi Keislaman, Volume 4, Nomor 1, Maret 2014, 4(1), 2-14.

Muyaroah, S., \& Fajartia, M. (2017). Pengembangan Media Pembelajaran Berbasis Android dengan menggunakan Aplikasi Adobe Flash CS 6 pada Mata Pelajaran Biologi. Innovative Journal of Curriculum and Educational Technology, 6(2), 2226. https://doi.org/10.15294/ijcet.v6i2.19336

Oktarini, D., Jamaluddin, J., \& Bachtiar, I. (2014). Efektivitas Media Animasi Terhadap Hasil Belajar Biologi Siswa Smpn 2 Kediri. Prisma Sains : Jurnal Pengkajian Ilmu Dan Pembelajaran Matematika Dan IPA IKIP Mataram, 2(1), 1. https://doi.org/10.33394/j-ps.v2i1.1048

Pusdiklat Pegawai Kementerian Pendidikan dan Kebudayaan (2020). "Surat Edaran Mendikbud No 4 Tahun 2020 Tentang Pelaksanaan Kebijakan Pendidikan Dalam Masa Darurat Penyebaran Corona Virus Disease (COVID-19)," 24 Maret 2020. https://pusdiklat.kemdikbud.go.id/surat-edaran-mendikbud-no-4-tahun-2020 tentang-pelaksanaan-kebijakan-pendidikan-dalam-masa-darurat-penyebarancorona-virus-disease-covid-19.

Retnaningsih, R., Kurnianto, A., Tugasworo, D. `, Andhitara, Y., Ardhini, R., Satrioaji, H. W., \& Budiman, J. (2020). Ensefalitis pada Infeksi Corona Virus Disease 2019 (COVID-19): Sebuah Tinjauan Literatur. Medica Hospitalia : Journal of Clinical Medicine, 7(1A), 361-371. https://doi.org/10.36408/mhjcm.v7i1a.483

Sahroni, O., \& Nuryuniarti, R. (2020). Respon Mahasiswa Selama Pembelajaran Daring Pada Mata Kuliah Pancasila ( Studi Pada Mahasiswa Fakultas Kesehatan Universitas Muhammadiyah Tasikmalaya Tahun 2020 ). Jurnal Education and Development Institut Pendidikan Tapanuli Selatan, 8(3), 37-41. https://doi.org/https://doi.org/10.37081/ed.v8i3.1894

Sangaji, R., Miftahudin, \& S. (2019). Meningkatkan Hasil Belajar Ipa Biologi Menggunakan Media Pembelajaran Audio Visual Pada Siswa Kelas Viib Mts. Muhammdiyah 1 Kota Sorong. Biolearning Journal, 6(1), 16-19. https://doi.org/https://doi.org/10.36232/jurnalbiolearning.v6i1.251

Slavin, R. E. (2011). Educational psychology: Theory and practice. Bahasa Indonesia Psikologi pendidikan: teori dan praktik. Indeks.

Suyasa, I. M., \& Sedana, I. N. (2020). Mempertahankan Eksistensi Media Cetak Di Tengah Gempuran Media Online Maintain The Existence Of Printed Media In The Middle Exposed To Media Online. Jurnal Komunikasi Dan Budaya, 01, 56-64.

Syah, R. H. (2020). Dampak Covid-19 pada Pendidikan di Indonesia: Sekolah, Keterampilan, dan Proses Pembelajaran. SALAM: Jurnal Sosial Dan Budaya SyarI, 7(5). https://doi.org/10.15408/sjsbs.v7i5.15314

Utomo, A. P., Hasanah, L., Hariyadi, S., Narulita, E., Suratno, \& Umamah, N. (2020). The effectiveness of steam-based biotechnology module equipped with flash animation for biology learning in high school. International Journal of Instruction, 13(2), 463-476. https://doi.org/10.29333/iji.2020.13232a

Wuryanti, U., \& Kartowagiran, B. (2016). Pengembangan Media Video Animasi Untuk Meningkatkan Motivasi Belajar Dan Karakter Kerja Keras Siswa Sekolah Dasar. Jurnal Pendidikan Karakter, 6(2), 232-245. https://doi.org/10.21831/jpk.v6i2.12055 
Yusmiono, B. A. (2018). Media pembelajaran visual terhadap hasil belajar mahasiswa program studi pendidikan geografi di universitas PGRI Palembang. Faktor Jurnal Ilmiah Kependidikan, $\quad 5(1), \quad 1-8$. https://doi.org/http://dx.doi.org/10.30998/.v5i1.2148

Zed, M. (2014). Metode Penelitian Kepustakaan (3rd ed.). Yayasan Obor Indonesia. 